\title{
Oxygenated Acyclic Diterpenes with Anticancer Activity from the Irish Brown Seaweed Bifurcaria bifurcata
}

\author{
Vangelis Smyrniotopoulos ${ }^{1}$, Christian Merten ${ }^{2}$, Daria Firsova ${ }^{1}$, Howard Fearnhead ${ }^{3}$ \\ and Deniz Tasdemir $1,4,5, *$ (D) \\ 1 School of Chemistry, National University of Ireland Galway, University Road, H91 TK33 Galway, Ireland; \\ vsmy@hotmail.com (V.S.); dashafirsova63@gmail.com (D.F.) \\ 2 Organische Chemie 2, Ruhr-Universität Bochum, Universitätsstraße 150, 44801 Bochum, Germany; \\ christian.merten@ruhr-uni-bochum.de \\ 3 Pharmacology and Therapeutics, School of Medicine, National University of Ireland Galway, \\ University Road, H91 W2TY Galway, Ireland; howard.fearnhead@nuigalway.ie \\ 4 GEOMAR Centre for Marine Biotechnology (GEOMAR-Biotech), Research Unit Marine Natural Product \\ Chemistry, GEOMAR Helmholtz Centre for Ocean Research Kiel, Am Kiel-Kanal 44, 24106 Kiel, Germany \\ 5 Faculty of Mathematics and Natural Sciences, Kiel University, Christian-Albrechts-Platz 4, \\ 24118 Kiel, Germany \\ * Correspondence: dtasdemir@geomar.de; Tel.: +49-431-600-4430
}

Received: 28 October 2020; Accepted: 19 November 2020; Published: 23 November 2020

\begin{abstract}
Brown alga Bifurcaria bifurcata is a prolific source of bioactive acyclic (linear) diterpenes with high structural diversity. In the continuation of our investigations on Irish brown algae, we undertook an in-depth chemical study on the $n$-hexanes and chloroform subextracts of B. bifurcata that led to isolation of six new (1-6) and two known (7-8) acyclic diterpenes. Chemical structures of the compounds were elucidated by a combination of 1D and 2D NMR, HRMS, FT-IR, $[\alpha]_{D}$ and vibrational circular dichroism (VCD) spectroscopy. Compounds 1-8, as well as three additional linear diterpenes (9-11), which we isolated from the same seaweed before, were tested against the human breast cancer cell line (MDA-MB-231). Several compounds moderately inhibited the growth of the MDA-MB-231 cell line with $\mathrm{IC}_{50}$ values ranging from 11.6 to $32.0 \mu \mathrm{g} / \mathrm{mL}$. The present study carried out on the lipophilic extracts of the Irish B. bifurcata shows the enormous capacity of this seaweed to produce a large palette of acyclic diterpenes with diverse oxygenation and substitution patterns and promising bioactivities.
\end{abstract}

Keywords: Bifurcaria bifurcata; linear diterpene; brown alga; seaweed; VCD; anticancer activity

\section{Introduction}

Bifurcaria bifurcata R. Ross is a brown alga belonging to the family Sargassaceae (order Fucales). Due to its morphology (cylindrical thallus, rhizoidal holdfast and regular narrow forking), it is regarded as a cylindrical brown seaweed and named as brown forking weed or brown tuning fork weed [1,2]. It is found abundantly in the rocky shores of Northern Atlantic coast, stretching from Morocco to France, Southwest Britain and Western Ireland [1,3]. Chemically, B. bifurcata is a prolific seaweed, representing over $8 \%$ of the total metabolites of the family Sargassaceae [3,4]. Although fatty acids, steroids, carotenoids, phlorotannins, phenolic acids and flavonoids have been reported from this species [5-7], the acyclic diterpenes obtained from the lipophilic extracts of the seaweed represent the largest natural product class. These compounds originate from geranylgeraniol and bear a C16 backbone with four double bonds and five olefinic methyl groups. A wide array of substitutions, 
e.g., oxygenation at C-1, C-6, C-7, C-12 or C-13, or other rearrangements, such as different unsaturation patterns, terminal furan, butenolide or hydroxybutenolide ring formation, middle chain hydroxylations or isomerisation, lead to a wide diversity of acyclic diterpenes with high structural and stereochemical diversity. These intriguing compounds serve as chemotaxonomical markers and exhibit a wide array of ecological activities [2,3,8,9]. A number of pharmacological activities, e.g., antimicrobial, antiprotozoal, antitubercular, anti-inflammatory, anticancer and neuroprotective, have been reported from $B$. bifurcata extracts and acyclic diterpenes isolated therefrom [2,6,10-12].

We previously reported antiprotozoal and antimycobacterial activities of the Irish B. bifurcata [13] as well as the isolation and absolute configuration (AC) determination of the known acyclic diterpenes eleganediol (9) and bifurcane (10) and the new compound bifurcatriol (11) [14,15]. In the continuation of our interest in this brown algal species, we continued our chemical analyses on the $n$-hexanes and chloroform subextracts of $B$. bifurcata that led to the isolation of eight linear diterpenoids. Compounds 1-6 are new acyclic diterpenes, while $\mathbf{7 - 8}$ were previously reported from B. bifurcata $[9,16]$. Herein, we report the isolation and structure elucidation of 1-8 and the anticancer activity of Compounds 1-11.

\section{Results and Discussion}

The freeze-dried fronds of $B$. bifurcata were successively extracted with $\mathrm{CH}_{2} \mathrm{Cl}_{2}$ and $\mathrm{MeOH}$. A solvent-solvent extraction of the combined organic extract by a modified Kupchan partition scheme afforded the $n$-hexanes, $\mathrm{CHCl}_{3}$ and aqueous subextracts. The $n$-hexanes and $\mathrm{CHCl}_{3}$ subextracts were subjected to automated flash chromatography and RP-HPLC to yield compounds 1-8.

Compound 1 was isolated as a colorless oil. The molecular formula $\mathrm{C}_{20} \mathrm{H}_{32} \mathrm{O}_{3}$ was assigned based on a sodium adduct $m / z 343.2247[\mathrm{M}+\mathrm{Na}]^{+}$observed in its HRESIMS spectrum, indicating five double bond equivalents (DBEs). Its IR spectrum contained absorption bands typical for hydroxyl, conjugated carboxylic acid and alkene functions ( $v_{\max } 3369,1690$ and $1642 \mathrm{~cm}^{-1}$, respectively). The ${ }^{1} \mathrm{H}$ NMR spectrum of 1 (Table 1) revealed the presence of four methine protons at $\delta_{\mathrm{H}} 5.06$ $(\mathrm{t}, J=5.5 \mathrm{~Hz}, \mathrm{H}-6), \delta_{\mathrm{H}} 5.13$ (br. d, $\left.J=8.4 \mathrm{~Hz}, \mathrm{H}-14\right), \delta_{\mathrm{H}} 5.18(\mathrm{t}, J=6.7 \mathrm{~Hz}, \mathrm{H}-10)$ and $\delta_{\mathrm{H}} 5.66$ (br. s, H-2) and five olefinic methyl singlets at $\delta_{\mathrm{H}} 1.70\left(\mathrm{H}_{3}-16\right), \delta_{\mathrm{H}} 1.67\left(\mathrm{H}_{3}-17\right), \delta_{\mathrm{H}} 1.63\left(\mathrm{H}_{3}-18\right), \delta_{\mathrm{H}} 1.58\left(\mathrm{H}_{3}-19\right)$ and $\delta_{\mathrm{H}} 2.15\left(\mathrm{H}_{3}-20\right)$, plus an oxymethine proton at $\delta_{\mathrm{H}} 4.38(\mathrm{td}, J=8.4,5.3 \mathrm{~Hz}, \mathrm{H}-13)$. The ${ }^{13} \mathrm{C} \mathrm{NMR}$ spectrum (Table 2) contained 20 carbon resonances, which, in conjunction with the $g \mathrm{HSQC}$ spectrum, were sorted out into a carbonyl group $\left(\delta_{C} 169.1, C-1\right)$, four quaternary $\mathrm{sp}^{2}$, four $\mathrm{sp}^{2}$ methine, one $\mathrm{sp}^{3}$ oxymethine, five $\mathrm{sp}^{3}$ methylene and four tertiary methyl carbons. The comparison of these data with those of the known compound eleganediol (9) [14] indicated that $\mathbf{1}$ is a linear diterpene containing an $\mathrm{OH}$ substitution, four double bonds and a carboxylic acid group, fulfilling the required number (5) of DBEs within $\mathbf{1}$.

In order to confirm and the position of the carboxylic acid and the $\mathrm{OH}$ substitution, and thereby the planar structure of $\mathbf{1}$, we ran $g \mathrm{COSY}$ and $g \mathrm{HMBC}$ experiments. Three short spin systems were visible in the COSY spectrum. The first two proton networks included two methylene and one olefinic methine protons each, i.e., $\mathrm{H}_{2}-4 / \mathrm{H}_{2}-5 / \mathrm{H}-6$ (fragment a) and $\mathrm{H}_{2}-8 / \mathrm{H}_{2}-9 / \mathrm{H}-10$ (fragment $b$ ). The third network consisted of $\mathrm{H}_{2}-12$, the oxymethine proton $\left(\mathrm{H}-13, \delta_{\mathrm{H}} 4.38\right)$ and the olefinic methine $\mathrm{H}-14$, yielding the fragment $\mathrm{c}$. The obtained COSY fragments a-c were readily connected through ${ }^{1} \mathrm{H}-{ }^{13} \mathrm{C}$ HMBC correlations between H-6/C-8 and $\mathrm{H}_{3}-19 / \mathrm{C}-6$; H-10/C-12 and H-10/ $\mathrm{CH}_{3}-18$, and from terminal methyl groups $\mathrm{H}_{3}-16$ and $\mathrm{H}_{3}-17$ to both $\mathrm{C}-14$ and $\mathrm{C}-15$. The significantly downfield resonances of $\mathrm{C}-3$ $\left(\delta_{\mathrm{C}} 162.6\right), \mathrm{H}_{3}-20\left(\delta_{\mathrm{H}} 2.15\right)$ and $\mathrm{H}-2\left(\delta_{\mathrm{H}} 5.66\right)$, as well as the appearance of $\mathrm{H}-2$ as an isolated broad singlet, suggested the presence of a terminal carboxylic acid at C-1. Further evidence for the location of the carboxylic acid at C-1 was provided by the diagnostic HMBC cross peaks between $\mathrm{H}-2 / \mathrm{C}-1$, $\mathrm{H}_{3}-20 / \mathrm{C}-1$ and $\mathrm{H}_{3}-20 / \mathrm{C}-2$, plus a $\mathrm{W}$ coupling of $\mathrm{H}-2$ with $\mathrm{H}_{2}-4$ in the COSY spectrum. This finalised the gross structure of compound 1.

The NOESY spectrum of 1 assisted in the identification of the $E$ geometry of all double bonds, on the basis of key NOE couplings observed between $\mathrm{H}-2 / \mathrm{H}_{2}-4$ (for C-2), $\mathrm{H}-6 / \mathrm{H}_{2}-4, \mathrm{H}-6 / \mathrm{H}_{2}-8$ (for C-6), 
$\mathrm{H}-10 / \mathrm{H}_{2}-8, \mathrm{H}-10 / \mathrm{H}_{2}-12$ (for C-10) and finally between $\mathrm{H}-14 / \mathrm{H}_{2}-12$ (for C-14). The assignment of $\mathrm{H}_{3}-16$ as pro- $E$ and $\mathrm{H}_{3}-17$ as pro- $Z$ was possible due to additional NOE correlations between $\mathrm{H}-14 / \mathrm{H}_{3}-16$ and $\mathrm{H}-13 / \mathrm{H}_{3}-17$, respectively. The absolute configuration of the only stereogenic center at $\mathrm{C}-13$ was assigned by vibrational circular dichroism (VCD) spectroscopy. We have shown in a previous VCD study on eleganediol (9) and bifurcane (10) [14] that the C-13 stereocenter gives rise to a distinct VCD spectroscopic signature which is independent of the substitution at C-1. The experimental VCD spectrum of $\mathbf{1}$ showed the same spectral pattern as observed for $\mathbf{9}$ (Supplementary Materials Figure S42), which led us to conclude without further theoretical spectra analysis that the AC of $\mathbf{1}$ is also $13 S$.

The molecular formula $\mathrm{C}_{20} \mathrm{H}_{34} \mathrm{O}_{3}$ was assigned to compound 2 by its HRESIMS data $(\mathrm{m} / z 345.2398$ $\left.[\mathrm{M}+\mathrm{Na}]^{+}\right)$. Compound 2 was identified as possessing a 13S-hydroxygeranylgeraniol scaffold with high similarities to eleganediol (9). However, 1D NMR and the $g \mathrm{HSQC}$ spectra indicated that one of the vinylic methyl signals $\left(\mathrm{CH}_{3}-17\right)$ was replaced with a primary alcohol group $\left(\delta_{\mathrm{H}} 3.99 \mathrm{~d}\right.$ and $\delta_{\mathrm{H}} 4.25 \mathrm{~d}$, $\left.J=12.4 \mathrm{~Hz} ; \delta_{\mathrm{c}} 62.3, \mathrm{t}\right)$. These methylene protons only showed geminal coupling with each other on the $g \mathrm{COSY}$ spectrum. The HMBC spectrum that contained correlations between $\mathrm{H}_{3}-16 / \mathrm{C}-17 ; \mathrm{H}_{2}-17 / \mathrm{C}-14$ and $\mathrm{H}_{2}-17 / \mathrm{C}-16$ clearly proved that the $\mathrm{H}_{3}-17$ methyl group was converted to a hydroxymethylene function, completing the structure of 2 . The all- $E$ geometry of the double bond carbons and $S$ configuration of $\mathrm{C}-13$ were confirmed by the characteristic ${ }^{13} \mathrm{C}$ and ${ }^{1} \mathrm{H}$ resonances of 2 that were similar to those of compounds $\mathbf{1}$ and $\mathbf{9}[14,15]$.

The HRESIMS analysis of compound 3 revealed a molecular formula $\mathrm{C}_{20} \mathrm{H}_{34} \mathrm{O}_{3}$ (m/z 345.2402 $\left.[\mathrm{M}+\mathrm{Na}]^{+}\right)$. The detailed inspection of the 1D and 2D NMR data of compound 3 indicated that it was an analogue of bifurcatriol (11), which is 13S,7S-dihydroxygeranylgeraniol [15]. The only difference between the two compounds was the conversion of the $\mathrm{C}-13-\mathrm{OH}$ functionality in $\mathbf{1 1}$ to a ketone group $\left(\delta_{\mathrm{C}} 197.7\right)$ in 3 , which was also confirmed by the IR absorption band at $v_{\max } 1703 \mathrm{~cm}^{-1}$. The oxidation at $\mathrm{C}-13$ led to deshielding of $\mathrm{H}-14\left(\delta_{\mathrm{H}} 5.96\right), \mathrm{H}_{3}-17\left(\delta_{\mathrm{H}} 2.12\right)$ and $\mathrm{H}_{2}-12\left(\delta_{\mathrm{H}} 2.97,2 \mathrm{H}\right)$, with the latter resonating as an isolated singlet (Table 1 ). The position of the $\mathrm{C}-13$ ketone group was verified by the key HMBC correlations observed between $\mathrm{H}_{2}-12 / \mathrm{C}-13$ and $\mathrm{H}-14 / \mathrm{C}-13$. The inspection of its full 2D NMR data (DEPT-HSQC, COSY, HMBC and NOESY) supported the suggested structure of the ketoalcohol 3, as shown in Figure 1. An $S$ configuration was assigned to C-7 based on comparison of the 1D NMR data of 3 with those of bifurcatriol (11) [15], the C-13-hydroxy derivative of 3.

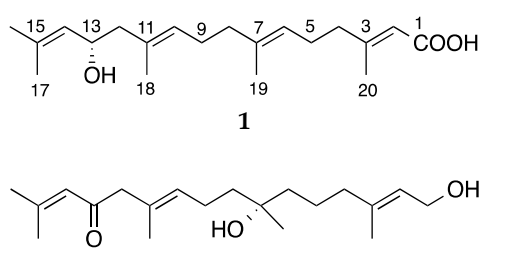

3
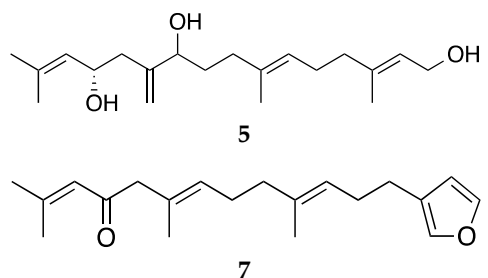

7

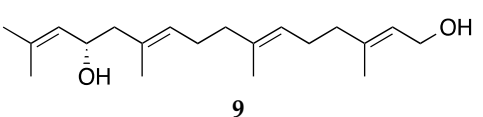<smiles>CC(=CCC(C)=CCCC(C)=CCCC(C)=CCCC(C)=CCO)CO</smiles><smiles>C=C(CC/C=C(\C)CCC(C)C)C(=O)CC/C=C/CO</smiles>

4<smiles>C=C(CCC=C(C)CCC=C(C)C[C@@H](O)C=C(C)C)C(O)CO</smiles><smiles>CC(C)=C[C@H](O)C/C(C)=C/CCC(C)(O)/C=C/C/C(C)=C/CO</smiles><smiles>CC(C)=C[C@H](O)C/C(C)=C/CC/C(C)=C/CCc1ccoc1</smiles><smiles>CC(C)=C[C@H](O)C/C(C)=C/CC[C@](C)(O)CCC/C(C)=C/CO</smiles>

Figure 1. Chemical structures of linear diterpenes 1-11. 
Table 1. ${ }^{1} \mathrm{H}$ NMR data of $1-6\left(\mathrm{CDCl}_{3}, 500 \mathrm{MHz}\right), \delta_{\mathrm{H}}$ values in ppm, $J$ in $\mathrm{Hz}$.

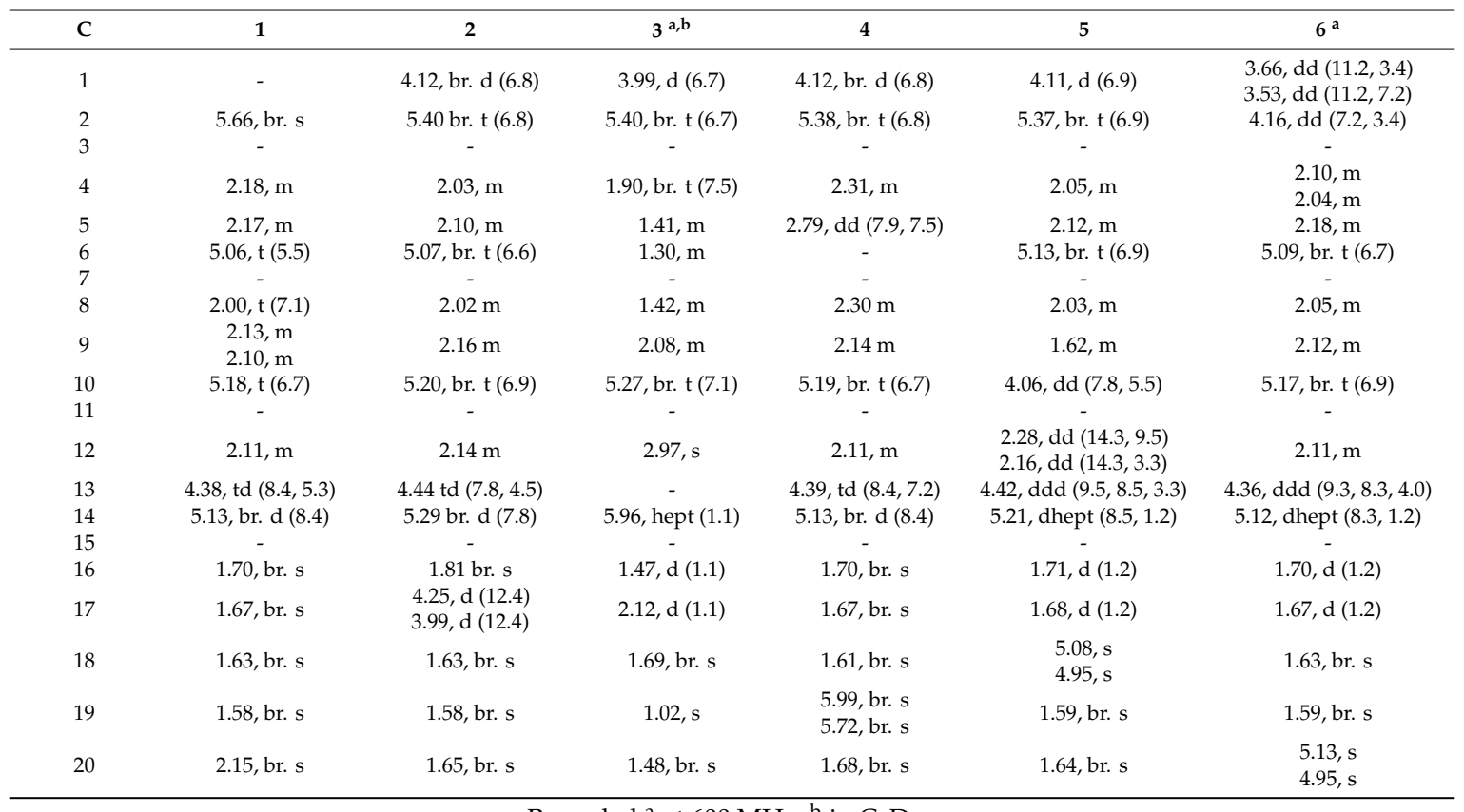

Recorded $^{\text {a }}$ at $600 \mathrm{MHz},{ }^{\text {b }}$ in $\mathrm{C}_{6} \mathrm{D}_{6}$.

Compound 4 was isolated as a colorless oil. The HRESIMS of 4 returned a sodium adduct ion at $m / z 343.2246[\mathrm{M}+\mathrm{Na}]^{+}$in agreement with a molecular formula $\mathrm{C}_{20} \mathrm{H}_{32} \mathrm{O}_{3}$ requiring five DBEs. A careful investigation of its $1 \mathrm{D}$ and 2D NMR spectra indicated that 4 lacked one of the olefinic methyl signals, but contained instead two broad singlets at $\delta_{\mathrm{H}} 5.99$ and $\delta_{\mathrm{H}} 5.72$, and a $\mathrm{CH}_{2}$ signal at $\delta_{\mathrm{C}} 124.2(\mathrm{t})$. Compound $\mathbf{4}$ had identical NMR data to those of $\mathbf{1}$ and $\mathbf{9}$ regarding the three double bonds $\left(\Delta^{2,3}, \Delta^{10,11}\right.$ and $\left.\Delta^{14,15}\right)$ and four olefinic methyl groups $\left(\mathrm{CH}_{3}-16, \mathrm{CH}_{3}-17, \mathrm{CH}_{3}-18\right.$ and $\left.\mathrm{CH}_{3}-20\right)$, hence $\mathrm{CH}_{3}-19$ must have converted into an exomethylene group, to fulfil the fourth DBE. On the other hand, the notably deshielded resonance of $\mathrm{H}_{3}-19$ and $\mathrm{H}_{2}-5\left(\delta_{\mathrm{H}} 2.79 \mathrm{dd}, J=7.9,7.5 \mathrm{~Hz}\right.$, Table 1$)$ suggested the presence of a strong electronegative group in their vicinity. The ${ }^{13} \mathrm{C}$ signal at $\delta_{\mathrm{C}} 201.2$ (C-6) and the FT-IR absorption band at $v_{\max } 1718 \mathrm{~cm}^{-1}$ of 4 supported the presence of a ketone group either at $\mathrm{C}-6$ or $\mathrm{C}-8$. The latter option (C-8-oxo) was ruled out, as $\mathrm{H}_{2}-8$ was part of a proton network composed of $\mathrm{H}-10\left(\delta_{\mathrm{H}} 5.19\right), \mathrm{H}_{2}-9\left(\delta_{\mathrm{H}} 2.14\right)$ and $\mathrm{H}_{2}-8\left(\delta_{\mathrm{H}} 2.30\right)$ in the $g \mathrm{COSY}$ spectrum of 4 (Figure $\left.\mathrm{S} 26\right)$. Thus, the ketone group was assigned to $\mathrm{C}-6$. An in-depth analysis of the cross peaks in the HMBC spectrum of 4, particularly those between $\mathrm{H}_{2}-8 / \mathrm{C}-19$, H-9/C-8, $\mathrm{H}_{2}-19 / \mathrm{C}-7$ and $\mathrm{H}_{2}-19 / \mathrm{C}-8$ lent proof for the presence of the exomethylene function at $\mathrm{C}-19$, while further $\mathrm{HMBC}$ correlations from $\mathrm{H}_{2}-19, \mathrm{H}_{2}-4$, $\mathrm{H}_{2}-5$ and $\mathrm{H}_{2}-8$ to $\mathrm{C}-6$ corroborated the position of the oxo function at C-6. Identical NMR data around the only stereocenter $\mathrm{C}-13$ was indicative of the same $S$ configuration at $\mathrm{C}-13$.

Compound 5 had a molecular formula $\mathrm{C}_{20} \mathrm{H}_{34} \mathrm{O}_{3}$ deduced by its HRMS data $(\mathrm{m} / \mathrm{z} 345.2405$ $[\mathrm{M}+\mathrm{Na}]^{+}$). Analysis of the NMR spectra indicated that 5 is another 13S-hydroxygeranylgeraniol derivative comprising four olefinic methyl groups. It was evident from two singlets at $\delta_{\mathrm{H}} 4.95$ and $\delta_{\mathrm{H}} 5.08$ (1H each) that correlated with the $\mathrm{CH}_{2}$ signal at $\delta_{\mathrm{C}} 114.3$ on the $g \mathrm{HSQC}$ spectrum that one of the methyl groups $\left(\mathrm{CH}_{3}-18\right)$ was converted into an exomethylene group in 5. Furthermore, NMR signals at $\delta_{\mathrm{H}} 4.06(\mathrm{dd}, J=7.8,5.5 \mathrm{~Hz}, \mathrm{H}-10)$ and $\delta_{\mathrm{c}} 74.9$ (C-10) suggested the presence of an additional secondary alcohol group (Tables 1 and 2). The HMBC spectrum contained key correlations from $\mathrm{H}-10$ and $\mathrm{H}_{2}-12$ to C-18; from $\mathrm{H}_{2}-18$ to $\mathrm{C}-10, \mathrm{C}-11$ and C-12; and finally from $\mathrm{H}_{2}-8$ and $\mathrm{H}_{2}-9$ to $\mathrm{C}-10$ assigned, respectively, the exocyclic double bond to $\mathrm{C}-18$ and the second $\mathrm{OH}$ group to $\mathrm{H}-10$. Due to rapid decomposition of the compound 5 during the NOESY experiment, the stereochemistry at C-10 could not be assigned. The all- $E$ geometry of the double bond carbons and $S$ configuration of C-13 were confirmed by their characteristic ${ }^{13} \mathrm{C}$ and ${ }^{1} \mathrm{H}$ NMR resonances [14,15]. 
Table 2. ${ }^{13} \mathrm{C}$ NMR data of compounds $\mathbf{1 - 6}\left(\mathrm{CDCl}_{3}, 125 \mathrm{MHz}\right)$.

\begin{tabular}{ccccccc}
\hline $\mathbf{C}$ & $\mathbf{1}$ & $\mathbf{2}$ & $\mathbf{3}^{\mathbf{a}, \mathbf{b}}$ & $\mathbf{4}^{\mathbf{c}}$ & $\mathbf{5}$ & $\mathbf{6}^{\mathbf{a}}$ \\
\hline 1 & $169.1 \mathrm{~s}$ & $59.3 \mathrm{t}$ & $59.4 \mathrm{t}$ & $59.2 \mathrm{t}$ & $59.4 \mathrm{t}$ & $65.6 \mathrm{t}$ \\
2 & $114.5 \mathrm{~d}$ & $123.5 \mathrm{~d}$ & $125.0 \mathrm{~d}$ & $123.7 \mathrm{~d}$ & $123.5 \mathrm{~d}$ & $74.9 \mathrm{~d}$ \\
3 & $162.6 \mathrm{~s}$ & $139.4 \mathrm{~s}$ & $138.2 \mathrm{~s}$ & $138.3 \mathrm{~s}$ & $139.6 \mathrm{~s}$ & $148.2 \mathrm{~s}$ \\
4 & $41.0 \mathrm{t}$ & $39.2 \mathrm{t}$ & $40.3 \mathrm{t}$ & $33.6 \mathrm{t}$ & $39.5 \mathrm{t}$ & $32.3 \mathrm{t}$ \\
5 & $25.8 \mathrm{t}$ & $26.0 \mathrm{t}$ & $22.3 \mathrm{t}$ & $35.8 \mathrm{t}$ & $26.2 \mathrm{t}$ & $26.0 \mathrm{t}$ \\
6 & $123.2 \mathrm{~d}$ & $124.4 \mathrm{~d}$ & $41.9 \mathrm{t}$ & $201.2 \mathrm{~s}$ & $123.9 \mathrm{~d}$ & $124.1 \mathrm{~d}$ \\
7 & $136.0 \mathrm{~s}$ & $134.8 \mathrm{~s}$ & $71.9 \mathrm{~s}$ & $148.2 \mathrm{~s}$ & $135.1 \mathrm{~s}$ & $135.3 \mathrm{~s}$ \\
8 & $39.4 \mathrm{t}$ & $39.4 \mathrm{t}$ & $41.8 \mathrm{t}$ & $30.9 \mathrm{t}$ & $35.5 \mathrm{t}$ & $39.4 \mathrm{t}$ \\
9 & $26.3 \mathrm{t}$ & $26.1 \mathrm{t}$ & $23.3 \mathrm{t}$ & $26.8 \mathrm{t}$ & $33.9 \mathrm{t}$ & $26.1 \mathrm{t}$ \\
10 & $128.4 \mathrm{~d}$ & $129.1 \mathrm{~d}$ & $129.7 \mathrm{~d}$ & $127.6 \mathrm{~d}$ & $74.9 \mathrm{~d}$ & $128.6 \mathrm{~d}$ \\
11 & $131.7 \mathrm{~s}$ & $131.4 \mathrm{~s}$ & $130.1 \mathrm{~s}$ & $132.4 \mathrm{~s}$ & $148.7 \mathrm{~s}$ & $131.7 \mathrm{~s}$ \\
12 & $48.2 \mathrm{t}$ & $48.3 \mathrm{t}$ & $55.5 \mathrm{t}$ & $48.0 \mathrm{t}$ & $40.2 \mathrm{t}$ & $48.2 \mathrm{t}$ \\
13 & $65.7 \mathrm{~d}$ & $64.6 \mathrm{~d}$ & $197.7 \mathrm{~s}$ & $65.7 \mathrm{~d}$ & $69.0 \mathrm{~d}$ & $65.4 \mathrm{~d}$ \\
14 & $127.3 \mathrm{~d}$ & $129.6 \mathrm{~d}$ & $123.3 \mathrm{~d}$ & $127.4 \mathrm{~d}$ & $125.2 \mathrm{~d}$ & $127.0 \mathrm{~d}$ \\
15 & $135.0 \mathrm{~s}$ & $139.4 \mathrm{~s}$ & $154.7 \mathrm{~s}$ & $135.0 \mathrm{~s}$ & $136.8 \mathrm{~s}$ & $135.0 \mathrm{~s}$ \\
16 & $25.8 \mathrm{q}$ & $21.9 \mathrm{q}$ & $27.3 \mathrm{q}$ & $25.6 \mathrm{q}$ & $25.8 \mathrm{q}$ & $25.8 \mathrm{q}$ \\
17 & $18.2 \mathrm{q}$ & $62.3 \mathrm{t}$ & $20.6 \mathrm{q}$ & $18.0 \mathrm{q}$ & $18.2 \mathrm{q}$ & $18.2 \mathrm{q}$ \\
18 & $16.2 \mathrm{q}$ & $16.1 \mathrm{q}$ & $16.6 \mathrm{q}$ & $16.1 \mathrm{q}$ & $114.3 \mathrm{t}$ & $16.1 \mathrm{q}$ \\
19 & $15.9 \mathrm{q}$ & $15.8 \mathrm{q}$ & $27.0 \mathrm{q}$ & $124.2 \mathrm{t}$ & $16.1 \mathrm{q}$ & $15.9 \mathrm{q}$ \\
20 & $19.1 \mathrm{q}$ & $16.3 \mathrm{q}$ & $16.1 \mathrm{q}$ & $16.3 \mathrm{q}$ & $16.2 \mathrm{q}$ & $111.0 \mathrm{t}$ \\
\hline
\end{tabular}

As deduced by HREIMS $\left(\mathrm{m} / \mathrm{z} 345.2396[\mathrm{M}+\mathrm{Na}]^{+}\right)$, the new compound 6 was determined as a positional isomer of compound 5 with the same molecular formula $\mathrm{C}_{20} \mathrm{H}_{34} \mathrm{O}_{3}$. The only difference between the two compounds was the position of both the exocyclic double bond $\left(\delta_{\mathrm{H}} 4.95 \mathrm{~s}, \delta_{\mathrm{H}} 5.13 \mathrm{~s}\right.$; $\left.\delta_{\mathrm{c}} 111.0 \mathrm{t}\right)$ and the additional secondary $\mathrm{OH}$ group $\left(\delta_{\mathrm{H}} 4.16 \mathrm{dd}, J=7.2,3.4 \mathrm{~Hz}, \delta_{\mathrm{c}} 74.9\right)$. Thanks to the HMBC correlations observed between (i) from $\mathrm{H}_{2}-20$ to C-2, C- 3 and C-4, (ii) from H-2 to C-20, and from $\mathrm{H}_{2}-4$ to $\mathrm{C}-20$ and (iii) from $\mathrm{H}-2$ to $\mathrm{C}-1$ and $\mathrm{C}-3$, the olefinic methylene group was assigned to C-20 and the secondary alcohol to C-2. Similar to 5, compound 6 had low stability and decomposed during the final 2D NMR experiment (NOESY), hence the stereochemistry of C-2 remains unassigned.

In vitro anticancer activity of the isolated compounds was evaluated against the breast cancer cell line MDA-MB-231. The only compounds that displayed activity were the new compound $1\left(\mathrm{IC}_{50} 30.7 \mu \mathrm{g} / \mathrm{mL}\right)$ and the known compounds $9\left(\mathrm{IC}_{50} 11.6 \mu \mathrm{g} / \mathrm{mL}\right)$ and $10\left(\mathrm{IC}_{50} 32.0 \mu \mathrm{g} / \mathrm{mL}\right)$. Compounds 7, 8 and 11 were inactive even at the highest test concentrations $(100 \mu \mathrm{g} / \mathrm{mL})$, while the remaining new compounds 2-6 were not tested due to availability of minute amounts or stability issues.

The present study has shown the Irish brown alga B. bifurcata to contain a wide array of linear diterpenes. Oxygenation in multiple positions is common in many acyclic diterpenes obtained from this seaweed [2,3,16-18]. Notably, all compounds isolated herein possessed oxygenation at C-13 accompanied by additional hydroxy, ketone, carboxylic acid substitutions or a terminal furan ring. We have previously applied VCD spectroscopy for identification of the absolute configuration $(S)$ of linear diterpenes from this seaweed, e.g., eleganediol (9) and bifurcane (10) [14], with a single stereocenter (C-13) as well as for bifurcatriol (11) that bears two stereocenters (C-7, C-13) [15]. In the present study, it was again successfully applied to confirm the (S)-configuration of C-13 in compound 1 . By structural analogy, NMR data comparison and biosynthetic considerations, we easily assigned $13 S$ stereochemistry to the other new compounds 2-6.

Numerous algal metabolites belonging to different natural product classes have been shown to exert anticancer activity $[19,20]$. The halogenated monoterpene halomon or the highly oxygenated triterpene laurenmariannol represent well-known examples of seaweed-derived terpenes with low to submicromolar level cytotoxicity [19], indicating the understudied potential of seaweeds. As for B. bifurcata, several C-12 hydroxy-bearing linear diterpenes have been reported with such potential and their potency [19-22] is generally similar to $\mathrm{C}-13 \mathrm{OH}-$ bearing acyclic diterpenes isolated in this study. 
In summary, the current study implies the diversity of polyoxygenated acyclic diterpenes in Irish brown alga $B$. bifurcata. Only three compounds showed modest anticancer activity against human breast cancer cells (MDA-MB-231). Several compounds could not be assessed for their bioactivity due to stability issues or low amounts available. Some compounds obtained in large amounts previously (e.g., 9 and 10) [14] can be submitted to semi-synthesis studies for enhancement of their anticancer potency and assessment of their further biological and ecological activities.

\section{Materials and Methods}

\subsection{General Experimental Procedures}

Optical rotations were determined with a Unipol L1000 Schmidt + Haensch polarimeter at the sodium D line $(589.3 \mathrm{~nm})$, at $20^{\circ} \mathrm{C}$, with a $10 \mathrm{~cm}$ cell. UV spectra were acquired in spectroscopic grade $\mathrm{CHCl}_{3}$ or $\mathrm{MeOH}$ on a Varian, Cary $100 \mathrm{UV}$-Vis spectrophotometer. IR spectra were recorded on a Perkin Elmer 400 or a Perkin Elmer Spectrum One ATR FT-IR spectrometer. NMR spectra were acquired using a Jeol $400 \mathrm{MHz}$, a Varian $500 \mathrm{MHz}$ or an Agilent $600 \mathrm{MHz}$ spectrometer. Chemical shifts are given on the $\delta(\mathrm{ppm})$ scale, referenced to the residual solvent signal $\left(\mathrm{CDCl}_{3}: \delta_{\mathrm{H}} 7.24, \delta_{\mathrm{C}} 77.0\right.$ or $\left.\mathrm{C}_{6} \mathrm{D}_{6}: \delta_{\mathrm{H}} 7.16, \delta_{\mathrm{C}} 128.0\right)$, and $J$ values in Hz. High-resolution mass spectrometric data were measured on an Agilent QTOF 6540 MS system, with electrospray ionisation (ESI) in the positive ion mode, coupled to an Agilent 1290 Infinity UPLC system, operating on the elution gradient: $50 \%$ B for 8 min, increasing to $100 \% \mathrm{~B}$ in $3 \mathrm{~min}$, maintaining $100 \% \mathrm{~B}$ for $5 \mathrm{~min}$ (solvent $\mathrm{A}: \mathrm{H}_{2} \mathrm{O}+0.1 \%$ formic acid, solvent B: $\mathrm{MeCN}+0.1 \%$ formic acid $)$, on a Zorbax Eclipse Plus C18 RRHD $(50 \times 2.1 \mathrm{~mm}, 1.8 \mu \mathrm{m})$ column, at $0.5 \mathrm{~mL} / \mathrm{min}$, with UV detection at 200-600 $\mathrm{nm}$. Thin layer chromatography (TLC) was performed with Kieselgel 60 F254 aluminium support plates (Merck) and spots were detected after spraying with $6 \%$ vanillin and $15 \% \mathrm{H}_{2} \mathrm{SO}_{4}$ in $\mathrm{MeOH}$ reagent. All solvents were of HPLC or LCMS grade and were purchased from Sigma-Aldrich.

\subsection{Algal Material}

Bifurcaria bifurcata was collected from the intertidal rock pool at Kilkee, Co. Clare of Ireland, in May 2009. A voucher specimen is kept at the Herbarium of the Biodiscovery Laboratory in the Irish Marine Institute (BDV0015).

\subsection{Extraction and Isolation}

The algal thalli were cleaned with sea water. $\mathrm{CH}_{2} \mathrm{Cl}_{2}$ and $\mathrm{MeOH}$ were used for exhaustive extraction of the freeze-dried material (132.4 $\mathrm{g}$ dry weight) at room temperature. The organic extracts were combined and evaporated to dryness on a rotary evaporator. The resulting dark green paste (12.0 g) was subjected to a modified Kupchan liquid-liquid partition. Briefly, the crude extract was dissolved in $90 \% \mathrm{MeOH}(200 \mathrm{~mL})$ and partitioned against $n$-hexanes $(3 \times 200 \mathrm{~mL})$. The water concentration was increased to $35 \%$, before partitioning against $\mathrm{CHCl}_{3}$. Evaporation of the solvents under reduced pressure and temperature afforded $n$-hexanes $(3.6 \mathrm{~g})$ and $\mathrm{CHCl}_{3}$ subextracts $(7.6 \mathrm{~g})$.

An aliquot of the $n$-hexanes subextract $(2.3 \mathrm{~g})$ was chromatographed by flash column chromatography over silica gel using a 10\% gradient of EtOAc in hexane to afford nine combined fractions (H1-H9). Fr. H2 (547 mg) which, eluted with 20\% EtOAc, was subjected to fractionation on an Agilent 971FP system loaded with a pre-packed silica column SF15-12g (Agilent), operating at the following gradient: $0 \% \mathrm{~B}$ for $10 \mathrm{~min}$, increasing to $6 \% \mathrm{~B}$ in $50 \mathrm{~min}$, increasing to $10 \% \mathrm{~B}$ in $20 \mathrm{~min}$, increasing to $100 \%$ B in 10 min, maintaining 100\% B for 15 min (solvent A: $n$-hexanes, solvent B: EtOAc), at a flow of $15 \mathrm{~mL} / \mathrm{min}$, to afford $7(1.2 \mathrm{mg})$.

The $\mathrm{CHCl}_{3}$ subextract (6.8 g) was subjected to gradient flash CC fractionation (Agilent 971FP system, pre-packed Agilent silica column SF25-80g, operating with the following gradient: $0 \%$ B for $5 \mathrm{~min}$, to $5 \% \mathrm{~B}$ in $15 \mathrm{~min}$, at 5\% B for $10 \mathrm{~min}$, to $10 \% \mathrm{~B}$ in $10 \mathrm{~min}$, at $10 \%$ B for $10 \mathrm{~min}$, to $40 \% \mathrm{~B}$ in $40 \mathrm{~min}$, to $100 \%$ B in $10 \mathrm{~min}$, at $100 \%$ B for $10 \mathrm{~min}$, solvent A: $n$-hexanes, solvent B: EtOAc, flow of $25 \mathrm{~mL} / \mathrm{min}$, 
affording 21 fractions (C1-C21). Fr. C4 (43.9 mg) was subjected to RP-HPLC. The separation was conducted using an Agilent 1260 system equipped with a diode array and an ELSD detector (split flow) on a Kromasil $100 \mathrm{C} 185 \mathrm{u}(250 \times 8 \mathrm{~mm}, 5 \mu \mathrm{m}) \mathrm{HPLC}$ column. The gradient elution using $55 \% \mathrm{MeCN}$ for $13 \mathrm{~min}$, increasing to $100 \% \mathrm{MeCN}$ in $5 \mathrm{~min}$ and maintaining $100 \% \mathrm{MeCN}$ for $20 \mathrm{~min}$ (solvent A: $\mathrm{H}_{2} \mathrm{O}$, solvent $\mathrm{B}$ : $\left.\mathrm{MeCN}\right)$, at a flow of $1.5 \mathrm{~mL} / \mathrm{min}$, afforded $1(11.2 \mathrm{mg})$. Fr. C10 (118.0 mg) was subjected to RP-HPLC on the same system, using the same solvent gradient to afford pure $4(1.0 \mathrm{mg}$, $\left.t_{R} 25.9 \mathrm{~min}\right)$. Fr. C12 $(66.0 \mathrm{mg})$ was separated by RP-HPLC under the same conditions to afford pure 8 $\left(1.1 \mathrm{mg}, \mathrm{t}_{\mathrm{R}} 22.7 \mathrm{~min}\right), \mathbf{3}\left(1.0 \mathrm{mg}, \mathrm{t}_{\mathrm{R}} 25.9 \mathrm{~min}\right), \mathbf{5}\left(7.2 \mathrm{mg}, \mathrm{t}_{\mathrm{R}} 26.2 \mathrm{~min}\right)$ and $\mathbf{6}\left(1.7 \mathrm{mg}, \mathrm{t}_{\mathrm{R}} 26.8 \mathrm{~min}\right)$. Finally, the RP-HPLC purification of fr. C16 $(49.0 \mathrm{mg})$ under the same conditions yielded $2(0.9 \mathrm{mg})$.

\subsection{VCD Spectroscopy}

The IR and VCD spectra of 1 were recorded on a Bruker Vertex 70V spectrometer equipped with a PMA 50 module for polarisation-modulated measurements. Samples were held in a sealed $\mathrm{BaF}_{2}$ IR cell with $100 \mu \mathrm{m}$ path length (Specac). Both IR and VCD spectra were recorded at $4 \mathrm{~cm}^{-1}$ spectral resolution by accumulating 32 and $\sim 20,000$ scans, respectively. Baseline correction of the spectra was done by subtraction of the solvent spectra measured under identical conditions.

Compound 1: colorless oil; $[\alpha]_{\mathrm{D}}+9.4(c$ 0.32, $\mathrm{MeOH}),+4.6\left(\mathrm{c} 1.13, \mathrm{CHCl}_{3}\right) ; \mathrm{UV}\left(\mathrm{CHCl}_{3}\right) \lambda_{\max }$ $(\log \varepsilon) 243(2.19) \mathrm{nm}$; IR (thin film) $v_{\max } 3369,2917,1690,1642,1437,1247,1157,1022,868 \mathrm{~cm}^{-1}$; ${ }^{1} \mathrm{H}$ NMR $\left(500 \mathrm{MHz}, \mathrm{CDCl}_{3}\right)$ and ${ }^{13} \mathrm{C}$ NMR $\left(125 \mathrm{MHz}, \mathrm{CDCl}_{3}\right)$ see Tables 1 and 2; HRESIMS $\mathrm{m} / z 343.2247$ $[\mathrm{M}+\mathrm{Na}]^{+}$(calcd for $\mathrm{C}_{20} \mathrm{H}_{32} \mathrm{O}_{3} \mathrm{Na}, 342.2244$ ).

Compound 2: colorless oil; $[\alpha]_{\mathrm{D}}-12.7\left(c 0.34, \mathrm{CHCl}_{3}\right)$; UV $\left(\mathrm{CHCl}_{3}\right) \lambda_{\max }(\log \varepsilon) 233$ (2.02) nm; IR (thin film) $v_{\max } 3422,2936,2872,1656,1459,1385,1193,1060 \mathrm{~cm}^{-1} ;{ }^{1} \mathrm{H} \mathrm{NMR}\left(500 \mathrm{MHz}, \mathrm{CDCl}_{3}\right)$ and ${ }^{13} \mathrm{C} \mathrm{NMR} \mathrm{(125} \mathrm{MHz,} \mathrm{CDCl}_{3}$ ) see Tables 1 and 2; HRESIMS $\mathrm{m} / z 345.2398[\mathrm{M}+\mathrm{Na}]^{+}$(calcd for $\mathrm{C}_{20} \mathrm{H}_{34} \mathrm{O}_{3} \mathrm{Na}$, 345.2400).

Compound 3: colorless oil; $[\alpha]_{\mathrm{D}}+6.0(c 0.10, \mathrm{MeOH}) ; \mathrm{UV}\left(\mathrm{CHCl}_{3}\right) \lambda_{\max }(\log \varepsilon) 245(2.23) \mathrm{nm}$; IR (thin film) $v_{\max } 3468,2932,1703,1022 \mathrm{~cm}^{-1} ;{ }^{1} \mathrm{H}$ NMR $\left(600 \mathrm{MHz}, \mathrm{C}_{6} \mathrm{D}_{6}\right)$ and ${ }^{13} \mathrm{C} \mathrm{NMR}(150 \mathrm{MHz}$, $\mathrm{C}_{6} \mathrm{D}_{6}$ ) see Tables 1 and 2; HRESIMS $\mathrm{m} / z 345.2402[\mathrm{M}+\mathrm{Na}]^{+}$(calcd for $\mathrm{C}_{20} \mathrm{H}_{34} \mathrm{O}_{3} \mathrm{Na}$, 345.2400).

Compound 4: colorless oil; $[\alpha]_{\mathrm{D}}-1.6\left(c 1.11, \mathrm{CHCl}_{3}\right)$; UV $\left(\mathrm{CHCl}_{3}\right) \lambda_{\max }(\log \varepsilon) 246(2.26) \mathrm{nm}$; IR (thin film) $v_{\max } 3492,2957,2874,1718,1456,1369,1240,1030,897,753 \mathrm{~cm}^{-1}$; ${ }^{1} \mathrm{H}$ NMR (500 MHz, $\left.\mathrm{CDCl}_{3}\right)$ and ${ }^{13} \mathrm{C} \mathrm{NMR}\left(125 \mathrm{MHz}, \mathrm{CDCl}_{3}\right)$ see Tables 1 and 2 ; HRESIMS $\mathrm{m} / z 343.2246[\mathrm{M}+\mathrm{Na}]^{+}$(calcd for $\mathrm{C}_{20} \mathrm{H}_{32} \mathrm{O}_{3} \mathrm{Na}$, 343.2244).

Compound 5: colorless oil; $[\alpha]_{\mathrm{D}}-12.7\left(c 0.34, \mathrm{CHCl}_{3}\right) ; \mathrm{UV}\left(\mathrm{CHCl}_{3}\right) \lambda_{\max }(\log \varepsilon) 236(2.18) \mathrm{nm}$; IR (thin film) $v_{\max } 3377,2942,2861,1378,1022 \mathrm{~cm}^{-1} ;{ }^{1} \mathrm{H} \mathrm{NMR}\left(500 \mathrm{MHz}, \mathrm{CDCl}_{3}\right)$ and ${ }^{13} \mathrm{C} \mathrm{NMR}(125 \mathrm{MHz}$, $\mathrm{CDCl}_{3}$ ) see Tables 1 and 2; HRESIMS $m / z 345.2405[\mathrm{M}+\mathrm{Na}]^{+}\left(\right.$calcd for $\mathrm{C}_{20} \mathrm{H}_{34} \mathrm{O}_{3} \mathrm{Na}$, 345.2400).

Compound 6: colorless oil; $[\alpha]_{\mathrm{D}}-3.1\left(c 1.09, \mathrm{CHCl}_{3}\right) ; \mathrm{UV}\left(\mathrm{CHCl}_{3}\right) \lambda_{\max }(\log \varepsilon) 234$ (1.98) nm; IR (thin film) $v_{\max } 3448,3225,2952,1683,1454,1378,1019 \mathrm{~cm}^{-1} ;{ }^{1} \mathrm{H} \mathrm{NMR}\left(600 \mathrm{MHz}, \mathrm{CDCl}_{3}\right)$ and ${ }^{13} \mathrm{C}$ NMR (150 MHz, $\mathrm{CDCl}_{3}$ ) see Tables 1 and 2; HRESIMS m/z 345.2396 (calcd for $\mathrm{C}_{20} \mathrm{H}_{34} \mathrm{O}_{3} \mathrm{Na}$, 345.2400).

\subsection{Anticancer Activity Assessments}

The breast cancer cell line MDA-MB-231 (ATCC) was maintained in Dulbecco's modified Eagle's medium (DMEM, Sigma-Aldrich) supplemented with $10 \%$ fetal bovine serum and $1 \%$ penicillin/streptomycin (Sigma-Aldrich) and incubated at $37{ }^{\circ} \mathrm{C}, 5 \% \mathrm{CO}_{2}$. MDA-MB-231 cells were seeded in a 96-well plate $\left(1 \times 10^{4}\right.$ cells per well $)$ and cultured for $24 \mathrm{~h}\left(37^{\circ} \mathrm{C}, 5 \% \mathrm{CO}_{2}\right)$ before being treated with extracts at a final concentration of $0-100 \mu \mathrm{g} / \mathrm{mL}$ (vehicle control: $1 \%$ DMSO; positive control: $10 \mu \mathrm{M}$ 5-Fluorouracil). After $72 \mathrm{~h}$, cell viability was assessed using Alamar Blue assay. Briefly, $40 \mu \mathrm{L}$ Alamar Blue $(0.56 \mathrm{mM})$ was added to each well containing $200 \mu \mathrm{L}$ of cell culture medium ( $93 \mu \mathrm{M}$ final Alamar Blue concentration). After $6 \mathrm{~h}$ incubation, the fluorescence of each well was assessed $\left(\lambda_{\mathrm{ex}}=530 \mathrm{~nm} ; \lambda_{\mathrm{em}}=595 \mathrm{~nm}\right)$ using a Victor $3 \mathrm{~V} 1420$ multilabel counter. Cell viability was calculated and expressed as a percentage of untreated control cells. The data are the mean \pm SD of three experiments and GraphPad Prism software was used to plot the data and to determine the $\mathrm{IC}_{50}$ values. 
Supplementary Materials: The following are available online at http://www.mdpi.com/1660-3397/18/11/581/s1, Supplementary Figures S1-S41: 1D and 2D NMR, HRESIMS and FT-IR spectra of compounds 1-6. Supplementary Figure S42: VCD spectra of 1 and $\mathbf{9 .}$

Author Contributions: Conceptualisation, D.T. and V.S.; investigation, V.S., C.M. and D.F.; resources, D.T., C.M. and H.F.; data curation, D.T., V.S., D.F. and C.M.; writing—original draft preparation, D.T.; writing-review and editing, D.T.; project administration, D.T.; funding acquisition, D.T. All authors have read and agreed to the published version of the manuscript.

Funding: This research was partly financially supported by the Beaufort Marine Research Award, carried out under the Sea Change Strategy and the Strategy for Science Technology and Innovation (2006-2013), with the support of the Marine Institute, funded under the Marine Research Sub-Programme of the National Development Plan 2007-2013. C.M. acknowledges support by the Deutsche Forschungsgemeinschaft (DFG, German Research Foundation) through the Heisenberg programme (ME 4267/5-1; project no. 418661145).

Acknowledgments: The authors thank S. Heesch for collection and identification of the algal material.

Conflicts of Interest: The authors declare no conflict of interest.

\section{References}

1. Bifurcaria bifurcata R.Ross. Available online: http://www.seaweed.ie/descriptions/Bifurcaria_bifurcata.php (accessed on 14 October 2020).

2. Pais, A.C.S.; Saraiva, J.A.; Rocha, S.M.; Silvestre, A.J.D.; Santos, S.A.O. Current research on the bioprospection of linear diterpenes from Bifurcaria bifurcata: From extraction methodologies to possible applications. Mar. Drugs 2019, 17, 556. [CrossRef]

3. Muñoz, J.; Culioli, G.; Köck, M. Linear diterpenes from the marine brown alga Bifurcaria bifurcata: A chemical perspective. Phytochem. Rev. 2013, 12, 407-424.

4. Rindi, F.; Soler-Vila, A.; Guiry, M.D. Taxonomy of marine macroalgae used as sources of bioactive compounds. In Marine Bioactive Compounds: Sources, Characterization and Applications; Hayes, M., Ed.; Springer: Boston, MA, USA, 2012; pp. 1-53.

5. Koch, M.; Glombitza, K.W.; Rösener, H.U. Polyhydroxyphenyl ethers from Bifurcaria bifurcata. Phytochemistry 1981, 20, 1373-1379.

6. Santos, S.A.O.; Trindade, S.S.; Oliveira, C.S.D.; Parreira, P.; Rosa, D.; Duarte, M.F.; Ferreira, I.; Cruz, M.T.; Rego, A.M.; Abreu, M.H.; et al. Lipophilic fraction of cultivated Bifurcaria bifurcata R. Ross: Detailed composition and in vitro prospection of current challenging bioactive properties. Mar. Drugs 2017, 15, 340. [CrossRef]

7. Agregán, R.; Munekata, P.E.S.; Franco, D.; Dominguez, R.; Carballo, J.; Lorenzo, J.M. Phenolic compounds from three brown seaweed species using LC-DAD-ESI-MS/MS. Food Res. Int. 2017, 99, 979-985. [PubMed]

8. Amico, V. Marine brown algae of family Cystoseiraceae: Chemistry and chemotaxonomy. Phytochemistry 1995, 39, 1257-1279.

9. Ortalo-Magné, A.; Culioli, G.; Valls, R.; Pucci, B.; Piovetti, L. Polar acyclic diterpenoids from Bifurcaria bifurcata (Fucales, Phaeophyta). Phytochemistry 2005, 66, 2316-2323. [PubMed]

10. Freile-Peregrin, Y.; Tasdemir, D. Seaweeds to the rescue of forgotten diseases: A review. Bot. Marina 2019, $62,211-226$.

11. Silva, J.; Alves, C.; Freitas, R.; Martins, A.; Pinteus, S.; Ribeiro, J.; Gaspar, H.; Alfonso, A.; Pedrosa, R. Antioxidant and neuroprotective potential of the brown seaweed Bifurcaria bifurcata in an in vitro Parkinson's disease model. Mar. Drugs 2019, 17, 85. [CrossRef]

12. Valls, R.; Banaigs, B.; Piovetti, L.; Archavlis, A.; Artaud, J. Linear diterpene with antimitotic activity from the brown alga Bifurcaria bifurcata. Phytochemistry 1993, 34, 1585-1588.

13. Spavieri, J.; Allmendinger, A.; Kaiser, M.; Casey, R.; Hingley-Wilson, S.; Lalvani, A.; Guiry, M.; Blunden, G.; Tasdemir, D. Antimycobacterial, antiprotozoal and cytotoxic potential of twenty-one brown algae (Phaeophyceae) from British and Irish waters. Phytotherapy Res. 2010, 24, 1724-1729.

14. Merten, C.; Smyrniotopoulos, V.; Tasdemir, D. Assignment of absolute configurations of highly flexible linear diterpenes from the brown alga Bifurcaria bifurcata by VCD spectroscopy. Chem. Commun. 2015, 51, 16217-16220.

15. Smyrniotopoulos, V.; Merten, C.; Kaiser, M.; Tasdemir, D. Bifurcatriol, a new antiprotozoal acyclic diterpene from the brown alga Bifurcaria bifurcata. Mar. Drugs 2017, 15, 245. [CrossRef] 
16. Hougaard, L.; Anthoni, U.; Christophersen, C.; Nielsen, P.H. Eleganolone derived diterpenes from Bifurcaria bifurcata. Phytochemistry 1991, 30, 3049-3051.

17. Valls, R.; Piovetti, L.; Banaigs, B.; Archavlis, A.; Pellegrini, M. (S)-13-Hyroxygeranylgeraniol-derived furanoditerpenes from Bifurcaria bifurcata. Phytochemistry 1995, 39, 145-149. [PubMed]

18. Culioli, G.; Daoudi, M.; Mesguiche, V.; Valls, R.; Piovetti, L. Geranylgeraniol-derived diterpenoids from the brown alga Bifurcaria bifurcata. Phytochemistry 1999, 52, 1447-1454.

19. Lefranc, F.; Koutsaviti, A.; Ioannou, E.; Kornienko, A.; Roussis, V.; Kiss, R.; Newman, D. Algae metabolites: From in vitro growth inhibitory effects to promising anticancer activity. Nat. Prod. Rep. 2019, 36, 810-841. [PubMed]

20. Kiruba, N.J.M.; Pradeep, M.A.; Thatheyus, A.J. Discovering promising anti-cancer drug candidates from marine algae. Sci. Int. 2018, 6, 44-50.

21. Zee, O.P.; Kim, D.K.; Choi, S.U.; Lee, C.O.; Lee, K.R. A new cytotoxic acyclic diterpene from Carpesium divaricatum. Arch. Pharm. Res. 1999, 2, 225-227.

22. Culioli, G.; Ortalo-Magne, A.; Daoudi, M.; Thomas-Guyon, H.; Valls, R.; Piovetti, L. Trihydroxylated linear diterpenes from the brown alga Bifurcaria bifurcata. Phytochemistry 2004, 65, 2063-2069. [PubMed]

Publisher's Note: MDPI stays neutral with regard to jurisdictional claims in published maps and institutional affiliations.

(C) 2020 by the authors. Licensee MDPI, Basel, Switzerland. This article is an open access article distributed under the terms and conditions of the Creative Commons Attribution (CC BY) license (http://creativecommons.org/licenses/by/4.0/). 